\title{
CIMAHI RIVER BENCHMARKING FLOOD ANALYSIS BASED ON THRESHOLD OF TOTAL RAINFALL
}

\author{
Safarina Ariani Budi ${ }^{1}$, Ramli ${ }^{2}$ \\ ${ }^{I}$ Doctor of philosophy, Civil Engineering Department, Jenderal Achmad Yani University, Cimahi, Indonesia \\ ${ }^{2}$ Master of Civil Engineering, Civil Engineering Department, Jenderal Achmad Yani University, Cimahi, Indonesia
}

\begin{abstract}
Flood in Cimahi city coming from the overflow of Cimahi river is a disaster that often occur in the middle Cimahi and extends downstream region namely Bandung Regency which is still included in the Cimahi Watershed. Flood in Cimahi can earlier be estimated when the design intensity of rainfall determined and calculate the flow of the river from upstream to downstream.The purpose of this study was to determine total rainfall that caused the peak river discharge of Cimahi river in upper and middle cross section and could easily received. The method used in this study is an early warning flood with benchmarking discharge based on rainfall-runoff models in the Cimahi watershed derived from unit hydrograph synthetic Nakayasu of Cimahi river. The results obtained from this study is the peak discharge of the Cimahi river upstream at $Q=1.41 \mathrm{~m} 3 / \mathrm{s}$ and in the middle of the cross section of $Q=2.12 \mathrm{~m} 3 / \mathrm{s}$. Based on the measurements obtained bankfull discharge Cimahi river upstream cross section of $191.8 \mathrm{m3} / \mathrm{s}$ and bankfull discharge in the middle cross section is $556.26 \mathrm{~m} 3 / \mathrm{s}$. With the drainage coefficient of Cimahi city based on land use obtained 0,57, then obtained a threshold total rainfall causes of flooding in the upper and middle is respectively as high as $239 \mathrm{~mm}$ and $460 \mathrm{~mm}$. Threshold of Rainfall, bankfull discharge and Cimahi river cross section in this research integrated on the map namely Benchmarking Flood Diagram of Cimahi City that can be published to stakeholders and the public.
\end{abstract}

Keywords: bankfull discharge, benchmarking flood diagram, hydrograph, peak discharge, threshold of rainfall ***..-

\section{INTRODUCTION}

Cimahi watershed with the main stream is Cimahi River, its flow through Cimahi city, Bandung regency and West Bandung regency. These third densely populated region requires good spatial planning in order to be a disaster-free area, especially floods. Cimahi city consists of three subdistricts of North Cimahi, Central Cimahi, and South Cimahi with an area of $40.25 \mathrm{~km}^{2}$. Geographically, the region is like the basin in the north, with an altitude of 1040 $\mathrm{m}$ and like the slope of Mount Burangrang and Tangkuban Perahu in the south which a height around $685 \mathrm{~m}$ msl. River through Cimahi city is Cimahi River with an average water flow $38301 / \mathrm{s}$, and its five tributaries namely Cibodas, Ciputri, Cimindi, Cibeureum and Cisangkan. ([1] Government, 2013)

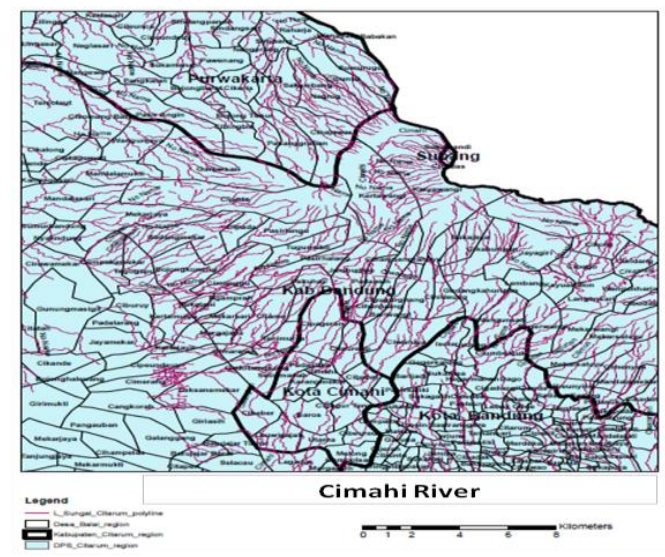

Fig-1 Cimahi River
Flooding on main roads Cimahi often occurs especially when the total rainfall peak around December to February. Cilember residence in Cigugur sub district on December $19^{\text {th }}, 2013$ affected by floods and flooded Amir Machmud main street. Water level reaches $1 \mathrm{~m}$ so that no vehicles can pass the provincial road causing traffic jams for more than 5 hours. Likewise Melong District of South Cimahi because of overflow of the Cibaligo river affecting impaired access to the Bandung city.

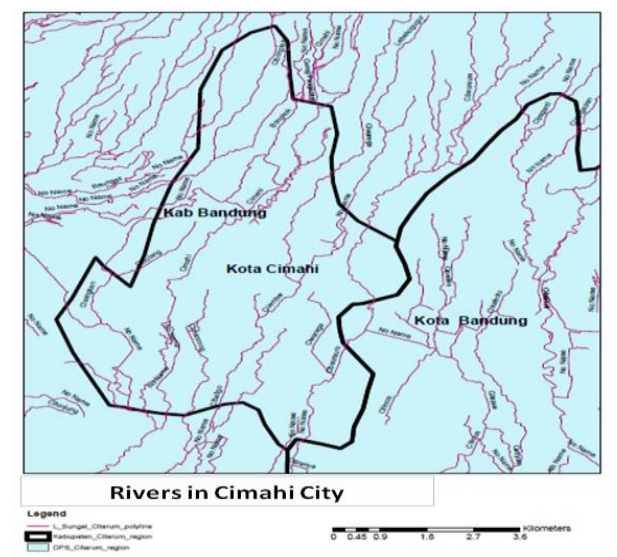

Fig-2 Rivers in Cimahi City

\subsection{Formulation of the Problem}

Cimahi city floods from overflowing river can be predicted early by determine the relationship between the river water level in some rivers cross section with the intensity of rainfall. This relationship can be determined by the intensity 
of rainfall that caused the water level of the river overflowed beyond the capacity of cross-section ([2] Chow, Maidment, \& L.W, 1988). Based on the relationship can also be seen that the peak time from the start of precipitation until the river water level reaches the highest water level. The peak time needed by stakeholders and the public in order to have enough time to anticipate the occurrence of floods.

\subsection{Goals of the Study}

Goals of this study are,

- Developed Cimahi unit hydrograph in the upper and middle Cimahi River

- Determine bankfull discharge of Cimahi River in the upper and in the middle cross section

- Determine the total rainfall threshold caused overtopping Cimahi River

- Create The Flood Diagrams of Cimahi City

\section{RAINFALL-RUNOFF MODEL}

Rainfall runoff models is a mathematical model that represents the mechanism of rainfall simulation in a watershed becomes runoff in the watershed outlet. First rainfall-runoff model used is the form of empirical equations developed from a region to other regions. The method developed after it is rational method, which is used to predict the peak discharge. After that Sherman (1932) from ([2] Chow, Maidment, \& L.W, 1988) found the unit hydrograf which is the first method that is not only determine the magnitude of peak flows. (Todini, 1988, from ([3] Kilgore, 1997))

\subsection{Hydrograph Analysis}

Hydrograph is one method of estimation of the flow of the river. The flow represents rainfall into the river, so flow hydrograf generated at the watershed outlet denote rainfallrunoff models at the specific watershed to convert the entire rainfall becomes flow hydrograf. Based on this concept, the method of unit hydrograf developed. ([4] Gupta Ram, 1989)

Unit hydrograph of a watershed is an excess rainfall hydrograph produced by $1 \mathrm{~mm}$ uniform excess rainfall at a constan rate during an effective duration. Unit hydrograph is a simple linear model which can be used to obtain flow hydrograph from any effective rainfall.

Synthetic unit hydrograph developed in ungaged watershed. The unit hydrograph can be used at different watershed which have same characteristic ([5] Safarina, Salim, Hardihardaja, \& BK, 2011). Dr Nakayasu (1941), from ([6] Soemarto, 1987), conducted research on rivers in Japan and he produces a synthetic unit hydrograph. Nakayasu Method is suitable for meso scale watershed. ([7] Safarina, 2012) Peak discharge of Nakayasu method is as follows,

$$
Q_{p}=\frac{C A R_{o}}{3,6\left(0,3 T_{p}+T_{0,3}\right)}
$$

Where,

$\mathrm{Q}_{\mathrm{p}}=$ peak discharge $\left(\mathrm{m}^{3} / \mathrm{s}\right)$

$\mathrm{A}=$ watershed area $\left(\mathrm{km}^{2}\right)$

$\mathrm{R}_{\mathrm{o}}=$ unit rainfall (mm)

$\mathrm{T}_{\mathrm{p}}=$ time lag from beginning rainfall up to peak discharge (jam)

$\mathrm{T}_{0,3}=$ time need for decreasing discharge starting from peak discharge

$\mathrm{C}=$ calibrated discharge coefficient $=0.9$

$\mathrm{T}_{\mathrm{p}}=\mathrm{t}_{\mathrm{g}}+0,8 \mathrm{t}_{\mathrm{r}}$

$\mathrm{t}_{\mathrm{r}}=0,5 \mathrm{t}_{\mathrm{g}}$

$\mathrm{t}_{\mathrm{g}}=0,4+0,058 \mathrm{~L}$

$\mathrm{T}_{0,3}=0.5 \mathrm{t}_{\mathrm{g}}$

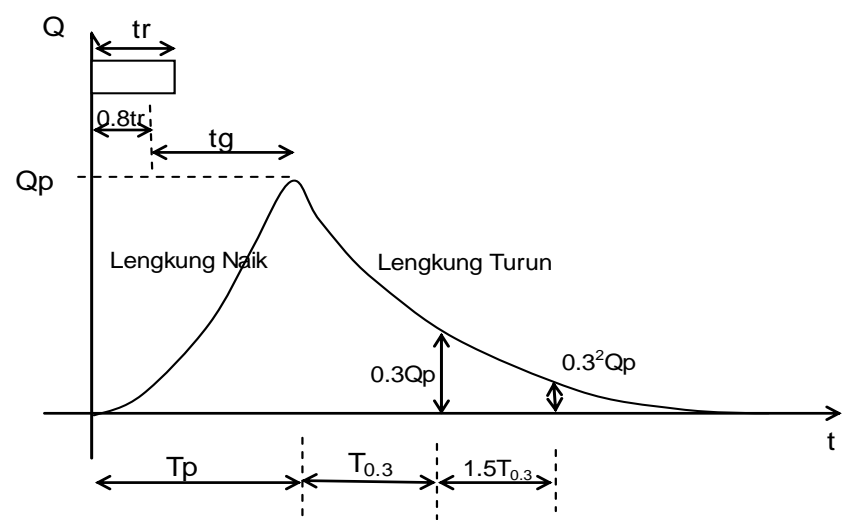

Fig-3 Nakayasu Synthetic Unit Hydrograph

\subsection{Overtopping of the River}

Flooding occurs due to overtopping of the river water level exceeded the maximum capacity or bankfull discharge. Bankfull capacity is described as follows,

Morphology of a river has a horizontal and vertical alignment. Horizontal alignment is the river flow and the vertical alignment is the cross-section of the river. The cross section of the river has a different shape along the river channel. According to Knighton, 1984 from ([8] Arbelaez, Guevara, Posada, \& Luis Jorge Gonzalez M, 2007), bankfull discharge does not have a constant frequency and also do not have the most effective flow, but has a reference water level that can be defined simply. The simplest definition is as shown in the following figure is reference to the discharge that is caused flooding in an active flood area. (Wolman and Leopold, 1957, ([8] Arbelaez, Guevara, Posada, \& Luis Jorge Gonzalez M, 2007))

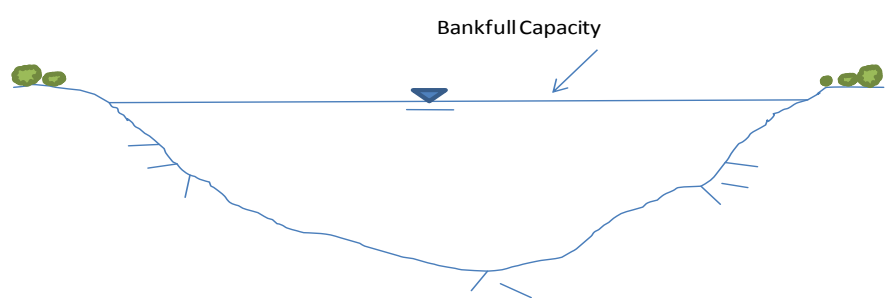

Fig-4 Bankfull Capacity 


\section{THRESHOLD OF TOTAL RAINFALL}

Based on rainfall-runoff model in a watershed, it could be obtained peak discharge, peak time and time base that occurred in the watershed outlet. The peak discharge shows the unit of maximum discharge that occur each $\mathrm{mm}$ at any effective rainfall so that when multiplied by convolution with effective rainfall, it will be produced the maximum discharge occurs in the watershed outlet. If the maximum discharge exceeded bankfull discharge, then there was a flood. Total rainfall that caused the flood discharge is called the threshold.of rainfall

Early flooding can be determined by the peak time i.e the lag time from the start of rainfall to reach the peak discharge. This time can be anticipated as early warning of flooding. In addition, the time base shows duration of inundation so it is an information when the magnitude of discharge in the watershed outlet as same as baseflow discharge again.

\section{BENCHMARKING SYSTEM OF URBAN FLOOD}

Flood's benchmarking is a flood standard used to measure the level of risk of flooding in areas that cut off by rivers or in places which have difficult topography. Benchmarking system can efficiently analysis for flooding that occurred in many points, because it is enough to determining the elevation in the benchmark point, than the elevation in the other points can be known.

\section{RESULTS AND DISCUSSION}

The results of this study consisted of Cimahi city drainage coefficient, unit hydrograph of Cimahi river in cross-section in the upstream and the middle which is adowntown of Cimahi city, bankfull discharge of Cimahi river in the upstream and the middle, threshold of total rainfall and flood benchmarking diagram of Cimahi city.

\subsection{Drainage Coefficient of Cimahi City}

Drainage coefficient at Cimahi city can be calculated based on the map of land-use. ([9] Hundecha \& Andras, 2004) Map of Cimahi City's landuse is showed as follows,

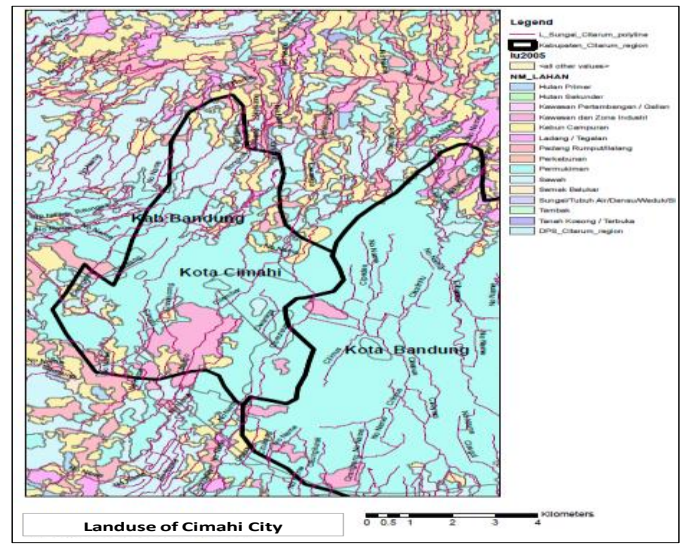

Fig-5 Landuse of Cimahi City
Drainage coefficient of Cimahi city can be seen in the following table,

Table-1 Drainage Coefficient of Cimahi City

\begin{tabular}{|l|c|c|c|}
\hline \multicolumn{2}{|c|}{ Landuse of Cimahi City } & Drainage Coef & Drainage Coefficient from \\
\cline { 1 - 2 } Type & Percentage (\%) & (c) & 0.0030 \\
\hline Fresh Water & 0.67 & 0.45 & 0.0217 \\
\hline bush & 5.42 & 0.4 & 0.0064 \\
\hline Building & 0.92 & 0.7 & 0.1149 \\
\hline forest & 22.98 & 0.5 & 0.0401 \\
\hline Plantation & 7.30 & 0.55 & 0.0002 \\
\hline Sand & 0.22 & 0.1 & 0.1993 \\
\hline Residence & 26.57 & 0.75 & 0.0130 \\
\hline Grass & 6.48 & 0.2 & 0.1130 \\
\hline Irrigation Paddy Field & 16.14 & 0.7 & 0.0020 \\
\hline Paddy Field without Irrigation & 0.27 & 0.75 & 0.0001 \\
\hline Pebbly & 0.04 & 0.3 & 0.0519 \\
\hline Field & 12.99 & 0.4 & 0.57 \\
\hline & \multicolumn{2}{|c|}{ Drainage Coefficient } &
\end{tabular}

\subsection{Unit Hydrograph of Cimahi River}

In this study unit hydrograph of Cimahi river will be calculated is the unit hydrograph at the upstream and middle cross section. This unit hydrograph can be used as a benchmarking flood of Cimahi city. The unit hydrograph computed by synthetic Nakayasu method. The results can be seen in the picture below,

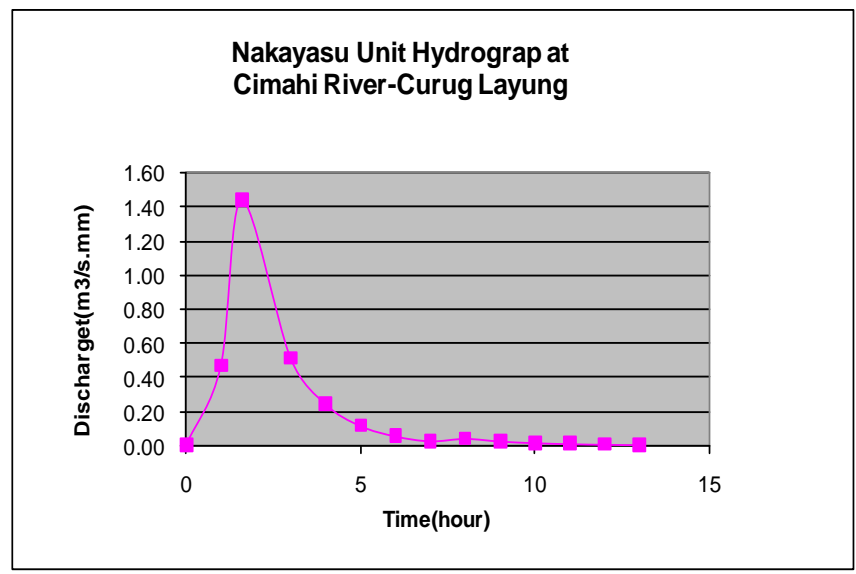

Fig-6 Unit Hydrogpah of Upstream Cimahi River

At the upstream is obtained magnitude of peak discharge equal to $1.4 \mathrm{~m}^{3} / \mathrm{s}$ for $1 \mathrm{~mm}$ excess rainfall, time to peak equal to 2 hour and time base equal to 13 hour.

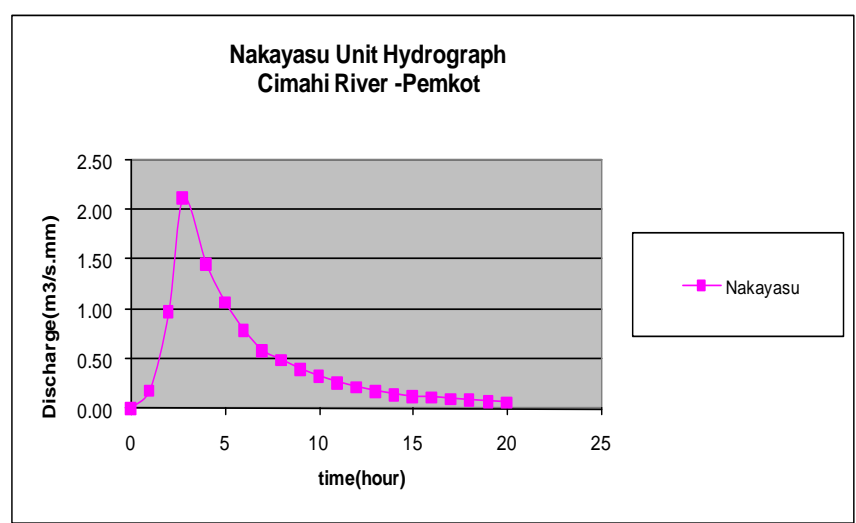

Fig-6 Unit Hydrogpah of Middle Cimahi River 
At the middle is obtained magnitude of peak discharge equal to $2.1 \mathrm{~m}^{3} / \mathrm{s}$ for $1 \mathrm{~mm}$ excess rainfall, time to peak equal to 3 hour and time base equal to 21 hour.

\subsection{Maximum Capacity of Cimahi River}

Cross section of Cimahi river in the upstream and its hydraulic parameter is showed as follows,

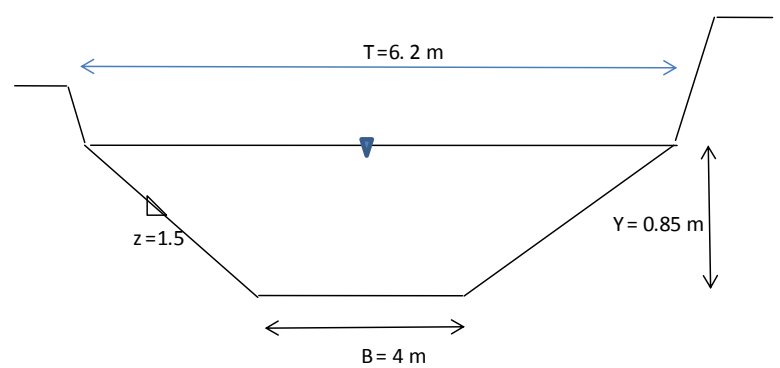

\begin{tabular}{|c|c|c|c|c|}
\hline$V=$ & 1.4 & $\mathrm{~m} / \mathrm{s}$ & & \\
\hline$T=$ & 6.2 & $\mathrm{~m}$ & & \\
\hline$b=$ & 4 & $\mathrm{~m}$ & & \\
\hline$z=$ & 1.5 & & & \\
\hline$y=$ & 0.85 & $\mathrm{~m}$ & & \\
\hline $\mathrm{I}=$ & 0.17 & & & \\
\hline & $D=$ & 0.72 & & \\
\hline & $P=$ & 7.06 & & \\
\hline & $A=$ & 4.48 & $\mathrm{~m} 2$ & \\
\hline & $\mathrm{R}=$ & 0.63 & & \\
\hline & $\mathrm{Q}=$ & 6.28 & $\mathrm{~m} 3 / \mathrm{s}$ & observation \\
\hline & & & & \\
\hline & $Q=$ & 45.51 & $\mathrm{~m} 3 / \mathrm{s}$ & manning \\
\hline & Qbankfull & 191.80 & $\mathrm{~m} 3 / \mathrm{s}$ & analisis \\
\hline & $\mathrm{F}=$ & 0.73586258 & & \\
\hline \multicolumn{5}{|c|}{ Cross section of Upstream Cimahi River, Curug Layung } \\
\hline \multirow{2}{*}{\multicolumn{2}{|c|}{$\begin{array}{l}\text { Coordinate } 6^{\circ} 46^{\prime} 19, ! \\
\text { Elevation } 1472 \mathrm{~m} \mathrm{msl}\end{array}$}} & dan & $107^{\circ} 34^{\prime}$ & BT \\
\hline & & & & \\
\hline
\end{tabular}

Fig-7 Cross Section of Upstream Cimahi River

Based on the upstream cross section of Cimahi river, it is obtained maksimum capacity at this cross section equal to $191.8 \mathrm{~m}^{3} / \mathrm{s}$. Middle cross section is as follows,

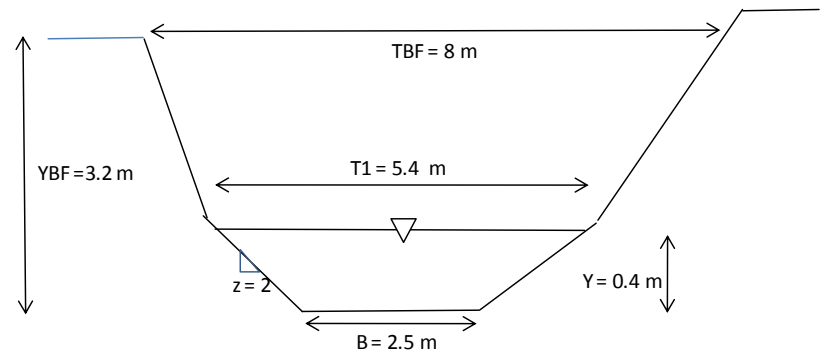

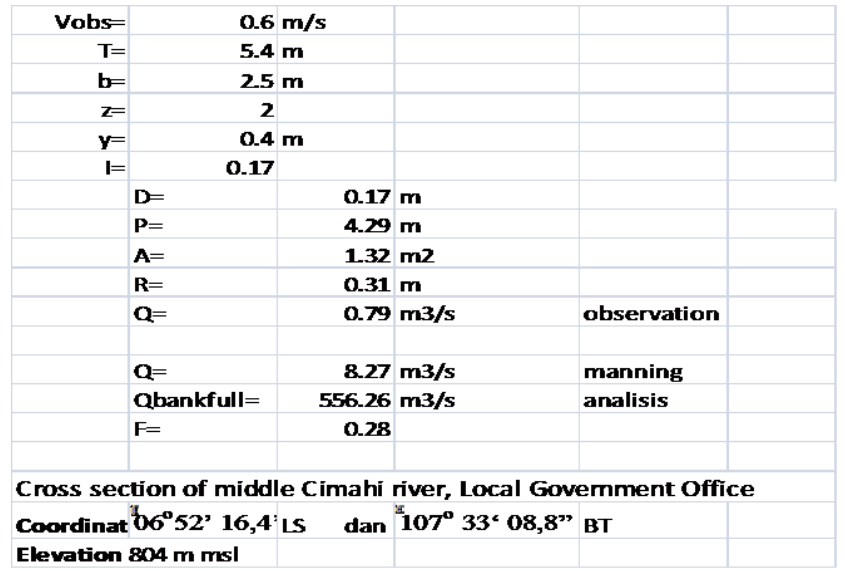

Fig-8 Cross Section of Middle Cimahi River

Cross section of the middle Cimahi river at an elevation of $804 \mathrm{~m}$ above mean sea level, has a discharge while in October $\mathrm{Q}_{\mathrm{obs}}=0.79 \mathrm{~m}^{3} / \mathrm{s}$ of measurement results and $\mathrm{Q}_{\bmod }$ $=8.27 \mathrm{~m}^{3} / \mathrm{s}$. From the analysis results obtained $\mathrm{Q}_{\text {bankfull }}=$ $556.26 \mathrm{~m}^{3} / \mathrm{s}$. Froude number at this cross section also shows the subcritical flow.

\subsection{Threshold of Total Rainfall}

Threshold of total rainfall can be seen at the table below,

Table-1 Threshold of Total Rainfall

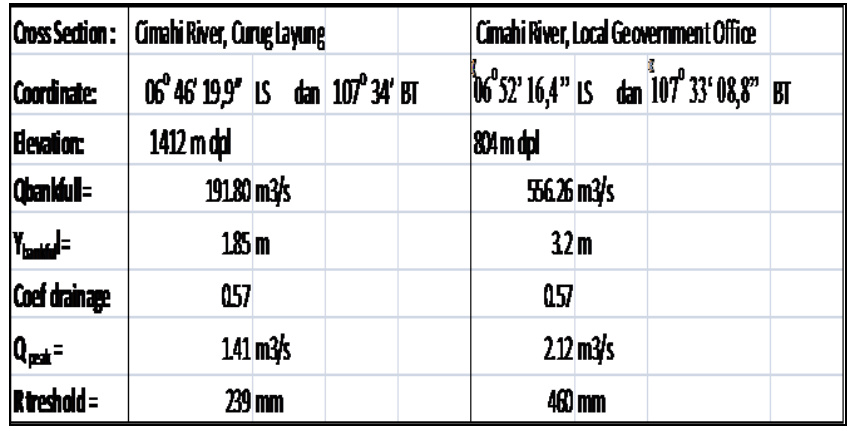

Threshold of total rainfall is obtained as $239 \mathrm{~mm}$ at the upstream and at the middle of Cimahi river. This value is very small and easy causing flood because an average total rainfall is about $460 \mathrm{~mm}$ for moderate rainfall. The location of middle cross section analized in this research is a center of Cimahi city, so if that section overtopping then all of Cimahi city will be waterlogged. To minimize the disaster, threshold of total rainfall and the unit hydrograph of Cimahi river can be used for benchmarking flood at Cimahi city so it will reduce losses such as traffic jams, property damage and traffic accidents.

\section{CONCLUSION}

Flood disaster management in urban areas can be minimized by providing early information to the public that can be categorized as an early warning method. Unit hydrograph in the center flood area can be used as a benchmarking flood by determine threshold of total rainfall that cause exceeding the maximum capacity of the river and result in overtopping in the river so there was a puddle in urban areas. 


\section{ACKNOWLEDGEMENTS}

I am grateful to the Jenderal Achmad Yani University which has funded this study and to the government of Cimahi city that has given support to the observations in the field.

\section{REFERENCES}

[1]. Government, C. (2013, January Monday). Data of Geography. Retrieved March Saturday, 2014, from www.cimahikota.go.id:

http://www.cimahikota.go.id/page/detail/4

[2]. Chow, V. T., Maidment, \& L.W, M. (1988). Applied Hydrology. Illinois: McGraw Hill International Edition.

[3]. Kilgore, J. (1997). Development and Evaluation of A GIS-Based Spatially Distributed Unit Hydrograph Model. Balcksburg: Biological Systems Engineering, Faculty of The Virginia Polytechnic and State University.

[4]. Gupta Ram, S. (1989). Hydrology and Hydraulic System. New Jersey: Prentice Hall.

[5]. Safarina, A. B., Salim, H. T., Hardihardaja, I. K., \& BK, M. S. (2011). Clusterization of Synthetic Unit Hydrograph Methods Based on Watershed Characteristics. International Journal of Civil and Environmental Engineering , 76-85.

[6]. Soemarto, C. (1987). Hidrologi Teknik. Surabaya,Indonesia: Usaha Nasional.

[7]. Safarina, A. B. (2012). Modified Nakayasu Synthetic Unit Hydrograph for Meso Scale Ungauge Watershed. International Journal of Engineering Research and Application , 649-654.

[8]. Arbelaez, A. C., Guevara, M. E., Posada, L. G., \& Luis Jorge Gonzalez M, C. A. (2007). Bankfull Discharge in Mountain Streams in the Cauca Region of Colombia. Colombia: Hidrology Days.

[9]. Hundecha, Y., \& Andras, B. (2004). Modelling of The Effect of Land Use Change on The Runoff Generation of a River Basin Through Parameter Regionalization of a Watershed Model. Journal of Hydrology , 281-295.

\section{BIOGRAPHIES}

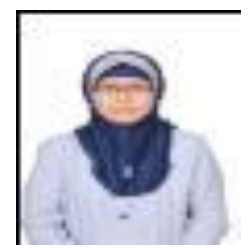

Ariani Budi Safarina is with the Jenderal Achmad Yani University, Doctor of hydrology and water resources engineering. Department of Civil Engineering, Cimahi, 40531, Indonesia (corresponding author to provide phone: 622-22-6641743; fax: 622-22- 6641743; e-mail: ariani.budi@ lecture.unjani.ac.id)

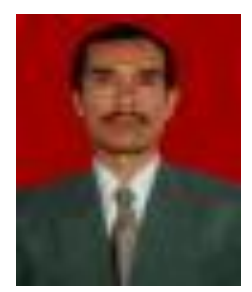

Ramli is with the Jenderal Achmad Yani University, Magister of Urban Traffic Engineering. Department of Civil Engineering, Cimahi, 40531, Indonesia (corresponding author to provide phone: 622-22-6641743; fax: 622-22- 6641743; e-mail: ramliemail@yahoo.com). 